\title{
Effect of Organic Sources of Nitrogen on Growth, Yield and Quality of King Chilli (Capsicum chinense Jacq.) under Poly House Condition
}

\author{
Humtu Rangai, A. K. Bijaya Devi", K. James Singh and S. Jekendra Singh \\ College of Agriculture, Central Agricultural University, Imphal, Manipur, India \\ *Corresponding author
}

\author{
A B S T R A C T
}

\begin{tabular}{l} 
K e y w or d s \\
$\begin{array}{l}\text { King chilli, Poly } \\
\text { house, Organic } \\
\text { sources, } \\
\text { Vermicompost, } \\
\text { Significant }\end{array}$ \\
\hline Article Info \\
$\begin{array}{l}\text { Accepted: } \\
22 \text { October } 2020 \\
\text { Available Online: } \\
10 \text { November } 2020\end{array}$ \\
\hline
\end{tabular}

\section{Introduction}

King chilli (Capsicum chinense Jacq.) or Ghost pepper also known as Umorok in Manipuri, Bhut Jolokia in Assamese and Naga Mircha in Nagamese, is chiefly cultivated in the north-eastern region of India, broadly in Manipur, Assam and Nagaland. King chilli is regarded as hottest chilli of India and was formerly recognized as world's hottest pepper with a Scoville Heat Units (SHU's) rating of 1,001,304 (Bosland and Baral, 2007).
A field investigation was conducted at the poly house of Department of Horticulture, COA, CAU, Imphal, during the rabi season 2019-20 to study the "Effect of organic sources of nitrogen on growth, yield and quality of king chilli". The layout of the experiment was Randomized Block Design with three replications under 8 different treatments. Results revealed that application of $100 \%$ RDF $\left(\mathrm{T}_{8}\right)$ registered significant values for plant height $(67.92 \mathrm{~cm})$, leaf length $(9.71 \mathrm{~cm})$, number of leaves $(116.63)$, plant canopy $\left(3118.60 \mathrm{~cm}^{2}\right)$, leaf area $\left(32.91 \mathrm{~cm}^{2}\right)$, number of fruits $(41.06)$, fruit yield $(8.55$ $\mathrm{t} / \mathrm{ha}$ ), seed yield (306.39 kg/ha) and harvest index (57.33\%). While, $\mathrm{T}_{3}(100 \% \mathrm{RDN}$ through vermicompost) recorded significant result for number of branches (19.60), fruit length $(6.27 \mathrm{~cm})$, fruit diameter $(2.65 \mathrm{~cm})$, fruit weight $(5.85 \mathrm{~g})$, number of seeds $(33.80)$ and least days to $1^{\text {st }}$ flowering (74.83 DAT) and 50\% flowering (90.23 DAT). The ascorbic acid content $(129.83 \mathrm{mg} / \mathrm{g})$ increased significantly under $\mathrm{T}_{6}(50 \% \mathrm{RDN}$ through $\mathrm{FYM}+$ $\%$ RDN through vermicompost + Azospirillum). The application of $100 \%$ RDF $\left(\mathrm{T}_{8}\right)$ recorded maximal net income ( $\square$ 1040320/ha) and highest B:C ratio (4.29) followed by $\mathrm{T}_{3}$ (100\% RDN through vermicompost). 
In Manipur, king chilli is traditionally grown in hill districts of the state in burned bamboo soils while jhum cultivation and also in kitchen gardens with some organic manures. The crop is usually sown in winter and harvested in summer months. The fruits are available in abundance during the peak period from May to September, yet there is critical gap in supply of king chilli fruits in the state from January to March and as a result prices shoot up. The farmers of Manipur are also facing problems of low seed viability and low productivity. In order to overcome these problems, it has become important to adopt king chilli cultivation under protected structures.

The cultivation under poly house results in crop protection from weather extremities, attack of insect pests \& diseases and helps to acquire yield 2-3 times more than open field situation. There will be an increased production of king chilli fruits under poly house farming without losing their colour and quality. The farmers will also fetch higher price in the market for their produce because of escalation in the prices of king chilli fruits. Thus, the cultivation of king chilli under poly house can play an important role in fulfilling the consumer's demand during the off season as it ensures the optimal utilisation of resources (land and water) for obtaining higher productivity.

The production of king chilli is affected by various biotic and abiotic factors, of which the requisite nutrient supplementation and growth environment are of prime importance. Ghost pepper is an exhaustive crop and being a heavy feeder responds very well to nutrient application. The nutrient supply to the plants can be achieved through different sources such as inorganic fertilizers, organic manures and biofertilizers. However, the broad utilization of synthetic fertilizers so as to increase production has questioned the nutritional security and furthermore its negative effect on the human wellbeing and condition.

Contrarily, organic farming system revamps soil health, keeps biological life cycle alive and helps in achieving considerable levels in yield. The produces obtained under organic farming are considerably more nutritious and healthy. Today, most farmers for this reason are seeking to organic farming practices to sustain agriculture production.

King chilli is an emerging crop and the large scale farming with respect to its improvement and production owing to its huge market demand, the use of organics in right proportion will be needed for its profitable cultivation.

Given the significance and huge potentiality of king chilli in national and international market, the study focused on revealing the standardization of organic farming practices under poly house condition to obtain higher yield of quality fruits under Manipur conditions along with their production economics.

\section{Materials and Methods}

The experiment was conducted in Randomized Block Design (RBD) with eight different treatments in three replications which are as follows:

$\mathrm{T}_{1}: 100 \%$ RDN through FYM

$\mathrm{T}_{2}: 100 \%$ RDN through poultry manure

$\mathrm{T}_{3}: 100 \%$ RDN through vermicompost

$\mathrm{T}_{4}: 50 \% \mathrm{RDN}$ through FYM $+50 \% \mathrm{RDN}$ through vermicompost

$\mathrm{T}_{5}: 50 \%$ RDN through vermicompost $+50 \%$ RDN through poultry manure

$\mathrm{T}_{6}: 50 \%$ RDN through FYM $+25 \%$ RDN through vermicompost + Azospirillum

$\mathrm{T}_{7}: 50 \%$ RDN through poultry manure $+25 \%$ 
RDN through vermicompost + Azospirillum

$\mathrm{T}_{8}: \operatorname{RDF}(120: 50: 50 \mathrm{~kg} \mathrm{NPK} / \mathrm{ha})$

\section{Organic manures application}

After the main bed preparation, required organic manures (FYM, vermicompost, poultry manure) were applied to each plot before transplanting of the seedlings in accordance to the treatments assigned. For each treatment, the quantity of equivalent organic manures were worked out according to the recommended dosage (120:50:50 NPK $\mathrm{kg} / \mathrm{ha}$ ). Azospirillum was incorporated in the soil at the time of transplanting by mixing it with FYM @ $2.5 \mathrm{~kg} / \mathrm{ha}$.

\section{Inorganic fertilizer application}

The inorganic fertilizers (Urea, SSP and MOP) were applied along the ridges @ 120:50:50 kg/ha. Full dose of phosphorus and potassium were applied at time of planting as basal application. Half of urea was applied as a basal dose $(60 \mathrm{~kg} \mathrm{~N} / \mathrm{ha})$ at transplanting time and remaining half later as top dressing, at two times, $30 \mathrm{~kg} \mathrm{~N} / \mathrm{ha}$ each time, at 30 and 60 days after transplanting.

\section{Transplanting of seedlings}

Two months old seedlings with 4-5 leaves were used for transplanting. Seedlings raised in poly bags were carefully removed and transplanted in the experimental plots at a spacing of $60 \mathrm{~cm} \mathrm{x} 45 \mathrm{~cm}$ on the same day in the evening hours. After transplanting, light irrigation was given.

\section{Growth parameters}

\section{Plant height (cm)}

The plant height was measured by selecting five randomly tagged plants in each treatment and their height was measured from ground level to growing tip of the main stem at 30 , 60, 90 and 120 DAT.

\section{Leaf length $(\mathrm{cm})$}

Leaf length was measured by selecting five leaves randomly per tagged plants with the help of a scale from the top to the end of the blade without petiole to the nearest $1 \mathrm{~mm}$.

\section{Number of leaves per plant}

The number of leaves per plant was accomplished by manual observation where the fully opened leaves on all five sample plants of each replication of treatments was counted and their average values were estimated at 30, 60, 90 and 120 DAT.

\section{Number of branches per plant}

Total number of branches per plant was counted from the five randomly selected and tagged plants at different growth stages. The mean number of branches per plant was worked out and expressed in number.

\section{Canopy of the plant $\left(\mathrm{cm}^{2}\right)$}

The canopy of each plant was measured crisscross wise with the help of scale at $30,60,90$ and 120 DAT.

\section{Leaf area $\left(\mathrm{cm}^{2}\right)$}

Leaf area of 5 sample plants in each treatment were recorded and average value was taken. Leaf area was calculated using the formula given by Meitei et al., (2005), $\mathrm{Y}=0.314+$ $0.560\left(X_{3}\right)$, where $X_{3}$ is the product of leaf length and breadth respectively.

\section{Days to $1^{\text {st }}$ flowering}

Regular observation was taken and data for days to first flower emergence were recorded 
randomly in each treatment by counting from days to transplanting till days to first flowering.

\section{Days to $50 \%$ flowering}

Days to $50 \%$ flowering were recorded when $50 \%$ of the plants in different treatments opened flowers fully.

\section{Yield attributes}

\section{Fruit length (cm)}

Fruit length of 20 randomly picked fruits from each replication of every treatment was measured with a vernier caliper from the neck of the fruit to the bottom of the fruit and the average value was taken.

\section{Fruit diameter (cm)}

Fruit diameter of 20 randomly picked fruits from each replication of every treatment from the sample plants was measured at the broad part of the fruit with the help of digital vernier calliper and the average value was taken.

\section{Fruit weight (g)}

Fruit weight of 20 randomly picked fruits from each replication of every treatment from the sample plants were measured with the help of electronic balance and the average value was taken.

\section{Number of fruits per plant}

Fruits from the five sample plants in each replication for every treatment were harvested and fruits per plant were calculated.

The total number of fruits per plant was counted for each picking and all the picked fruits were added, then their average was calculated.
Fruit yield per plant (g): Fruits from all the sample plants were harvested separately and weighed. Mean value was taken to find out fruit yield per plant.

Fruit yield per hectare (t/ha): Fruit yield per hectare was calculated from fruit yield per plant data taking plant population per hectare into consideration.

Number of seeds per fruit: Number of seed was obtained manually by slicing the chilli fruit and counting all the seeds contained in the pod. Seeds were extracted from 20 ripe fruits harvested from the sample plants of all treatments and were calculated. Means were taken.

Seed yield per plant (g): Seeds were extracted from each sample plant separately and mean value was taken to determine seed yield per plant.

Seed yield per hectare (kg): Seed yield per hectare was calculated from seed yield per plant data considering total plant population per hectare.

Harvest index (\%): Harvest index was calculated as ratio between economic yield and biological yield of the harvested plants and was multiplied by 100 to get the values in percentage.

$\mathrm{HI}=$ Economic yield $/$ Biological yield $\mathrm{x} 100$

Quality parameter: The quality parameter for ascorbic acid content was analysed after fruits from five sample plants in each replication for every treatment were harvested.

Ascorbic acid content (mg/100g): Ascorbic acid or Vitamin $\mathrm{C}$ content of fruit was determined using 2, 6-dichlorophenol indophenols dye method as given by Rangana 
(1977). The formula used were given as follows-

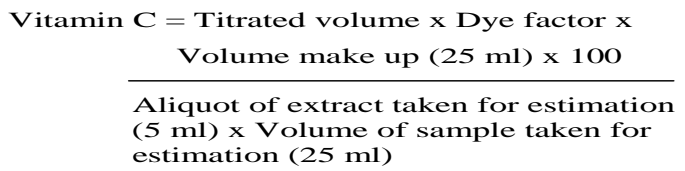

\section{Results and Discussion}

\section{Growth parameters}

The findings of the present experimentation revealed that significant variation among the statures of king chilli plant were observed at all crop growth stages except 30 DAT. The plant height increased notably with progression of time and responded positively to the different treatments. It was observed that plants supplied with inorganics treatment (120:50:50 $\mathrm{kg}$ NPK/ha) significantly remained superior over others at 120 DAT $(67.92 \mathrm{~cm})$. The split application of inorganic fertilizer i.e. half of urea at transplanting (60 $\mathrm{kg} \mathrm{N} / \mathrm{ha}$ ) and remaining half in two equal split doses (30 kg N/ha each time) at 30 and 60 days after transplanting must have made sufficient availability of nitrogen throughout the stages of crop growth resulting in increased height of plants. This finding is supported by Khutate et al., (2005), Medhe et al., (2010), Alex and Eliakira (2014), Omogoye (2015).

The growth parameters like leaf length and number of leaves also responded positively to the different treatment combinations. It was observed that plants supplied with $100 \%$ RDF $\left(\mathrm{T}_{8}\right)$ recorded the maximum values for leaf length and number of leaves followed by $100 \%$ RDN through vermicompost $\left(\mathrm{T}_{3}\right)$. The application of inorganic fertilizers $\left(\mathrm{T}_{8}\right)$ must have made sufficient availability of nitrogen during the early plant growth as the release of nutrients is quick and easier through inorganics resulting in increased vegetative growth of king chilli plants. This result is in conformity with the findings of Medhe et al., (2010) and Hussein Hussein Alhrout (2017).

Number of branches in king chilli were significantly influenced with the use of different nitrogen management practices at all the stages of crop growth except 30 DAT. Treatment application of $100 \%$ RDN through vermicompost $\left(\mathrm{T}_{3}\right)$ exhibited highest number of branches (19.60) at 120 DAT, but remained at par with $100 \%$ NPK i.e. $\mathrm{T}_{8}$ (17.73). Comparatively similar results have been obtained in chilli by Olson et al., (1971) and Singh et al., (2014). The use of vermicompost must have improved soil physical conditions and assured availability of nitrogen which further resulted in amino acid production and subsequently synthesis of protein and chlorophyll formation. The vermicompost addition thus encouraged vegetative growth and as a consequence produced significant number of branches in king chilli. This result is also in rational to the findings of Baloch $e t$ al., (2008) who reported that organic fertilizer application in chilli have significant effect on branches per plant as they contain most nutrients (both macro and micro) and cited that these fertilizers supplied nutrients to the plant.

Plant canopy and leaf area of king chilli are important growth contributing characters. As per the investigation, a gradual increase in canopy and leaf area was noticed with the advancement of crop growth till harvest. The maximum canopy and leaf area of king chilli plant was exhibited by the application of inorganics i.e. $100 \%$ RDF $\left(\mathrm{T}_{8}\right)$, but remained at par with $\mathrm{T}_{3} \quad(100 \%$ RDN through vermicompost) at all observation stages. This significant variation in plant canopy under $\mathrm{T}_{8}$ is presumably due to increased plant height, secondary branches and fertilizer requirement. Whereas, the increased leaf area under $\mathrm{T}_{8}$ is possibly due to increased leaf length, higher interception of light and high photosynthetic 
activity. The finding of Medhe et al., (2010) is also in agreement with this study.

The vermicompost application significantly enhanced induction of flowers as compared to others. The growth parameters like minimum days to $1^{\text {st }}$ flowering (74.83 DAT) and $50 \%$ flowering (90.23 DAT) was recorded in $\mathrm{T}_{3}$ (100\% RDN through vermicompost) which took least number of days as compared to inorganics (100\% RDF). This variation in flowering induction is presumably due to slow release of nutrients through vermicompost to the king chilli plant resulting in early flowering. On the other hand, chemical fertilizers (100\% NPK) must have supplied nutrients readily which increased vegetative growth and inevitably delayed flowering in king chilli. These results are in line with Adhikari et al., (2016). The reduction in days to first flowering under $T_{3}$ (100\% RDN through vermicompost) might also be because of further decomposition of vermicompost which must have augmented potassium concentration and increased temperature in the root zone of king chilli plants. Abu-Zahara (2012) also reported that with organic manures application in sweet pepper, days to first flowering are reduced as a result of temperature increase in the rhizosphere.

\section{Yield parameters}

Data presented in Table 2 indicated that substitution of $100 \%$ RDN through vermicompost $\left(T_{3}\right)$ registered significant values for fruit length $(6.27 \mathrm{~cm})$, fruit diameter $(2.65 \mathrm{~cm})$ and fresh weight of fruit $(5.85 \mathrm{~g})$ followed by $\mathrm{T}_{4}(50 \% \mathrm{RDN}$ through FYM + 50\% RDN through vermicompost), $\mathrm{T}_{6}$ $(50 \%$ RDN through FYM $+25 \%$ RDN through vermicompost + Azospirillum) and $\mathrm{T}_{8}$ (100\% NPK), all of them being at par. These results are supported by Yadav and Vijayakumari (2003), Khandaker et al.,
(2017) and Bilal et al., (2019). The vermicompost addition favors microbes population and speed up quicker substrate decomposition. The increased yield attributes under $T_{3}$ is possibly due to greater availability of macro nutrients for easy uptake by leaves of king chilli plants that must have heightened protein synthesis process and subsequently build up the translocation of organic compounds from the source to sink that are influenced by release of growth hormones from vermicompost. The findings are also in accordance with the work of (Pavan, 2013; Sivakumar et al., 1999), they noted that vermicompost application helped increased fruit length and fruit weight of chilli.

The supplementation of inorganics i.e. 100\% RDF $\left(T_{8}\right)$ significantly influenced number of fruits per plant (41.06), fruit yield per plant $(231.01 \mathrm{~g})$ and fruit yield per hectare $(8.55$ t/ha). However, $T_{8}$ remained at par with $\mathrm{T}_{3}$ (100\% RDN through vermicompost) and $\mathrm{T}_{4}$ (50\% RDN through FYM + 50\% RDN through vermicompost) in regard to fruits number and yield and fruit yield respectively. The findings are in line with the results of Medhe et al., (2010), Singh et al., (2012) and Alex and Eliakira (2014). The highest number of king chilli fruits under $T_{8}$ is possibly due to increased plant vigor and number of leaves per plant, whereas the increased fruit yield of king chilli under $\mathrm{T}_{8}$ might be due to highest number of fruits obtained under this treatment. This has conformity with Revanappa et al., (1997) who found that significant yield in chillies can be acquired due to higher number of fruits with improved fruit yield attributes. The higher fruit yield under $\mathrm{T}_{8} \quad(100 \%$ RDF $)$ might also be accompanied to inorganic fertilizers application as they contained soluble nutrients which are readily available to crops and therefore helped to produce increased yields (Chassy et al., 2006; Riahi et al., 2009). 
Table.1 Growth parameters of king chilli as influenced by various organic sources of nitrogen

\begin{tabular}{|c|c|c|c|c|c|c|c|c|}
\hline Treatments & $\begin{array}{c}\text { Plant } \\
\text { height } \\
\text { (cm) }\end{array}$ & $\begin{array}{c}\text { Leaf } \\
\text { length } \\
\text { (cm) }\end{array}$ & $\begin{array}{c}\text { No. of } \\
\text { leaves per } \\
\text { plant }\end{array}$ & $\begin{array}{c}\text { No. of } \\
\text { branches } \\
\text { per plant }\end{array}$ & $\begin{array}{c}\text { Leaf } \\
\text { area } \\
\left(\mathbf{c m}^{2}\right)\end{array}$ & $\begin{array}{c}\text { Plant } \\
\text { canopy } \\
\text { (.m } \mathbf{2})\end{array}$ & $\begin{array}{c}\text { Days to 1 } \\
\text { flowering }\end{array}$ & $\begin{array}{c}\text { Days to } \\
\mathbf{5 0 \%} \\
\text { flowering }\end{array}$ \\
\hline $\mathbf{T}_{\mathbf{1}}$ & 47.34 & 7.44 & 84.00 & 11.56 & 21.23 & 2229.52 & 85.43 & 106.20 \\
\hline $\mathbf{T}_{\mathbf{2}}$ & 54.13 & 8.08 & 93.86 & 14.20 & 24.14 & 2543.33 & 82.63 & 102.96 \\
\hline $\mathbf{T}_{\mathbf{3}}$ & 61.06 & 9.13 & 107.70 & 19.60 & 30.84 & 2915.18 & 74.83 & 90.23 \\
\hline $\mathbf{T}_{\mathbf{4}}$ & 59.09 & 8.75 & 103.13 & 17.16 & 28.11 & 2740.66 & 77.03 & 94.56 \\
\hline $\mathbf{T}_{\mathbf{5}}$ & 51.05 & 7.62 & 91.40 & 12.70 & 22.27 & 2363.33 & 83.23 & 103.73 \\
\hline $\mathbf{T}_{\mathbf{6}}$ & 57.18 & 8.45 & 98.33 & 16.23 & 27.31 & 2638.00 & 79.96 & 97.76 \\
\hline $\mathbf{T}_{\mathbf{7}}$ & 55.37 & 8.31 & 95.36 & 14.80 & 26.47 & 2591.66 & 80.40 & 98.30 \\
\hline $\mathbf{T}_{\mathbf{8}}$ & 67.92 & 9.71 & 116.63 & 17.73 & 32.91 & 3118.60 & 79.40 & 96.93 \\
\hline $\mathbf{S . E m}(\mathbf{E})$ & 2.22 & 0.27 & 2.85 & 0.78 & 1.16 & 76.45 & 1.59 & 2.44 \\
\hline $\mathbf{C D}(\mathbf{0 . 0 5})$ & 6.76 & 0.83 & 8.66 & 2.38 & 3.53 & 231.90 & 4.83 & 7.40 \\
\hline
\end{tabular}

Table.2 Yield parameters and quality aspect of king chilli as influenced by various organic sources of nitrogen

\begin{tabular}{|c|c|c|c|c|c|c|c|c|c|c|c|}
\hline Treatments & $\begin{array}{l}\text { Fruit } \\
\text { length } \\
\text { (cm) }\end{array}$ & $\begin{array}{c}\text { Fruit } \\
\text { diameter } \\
\text { (cm) }\end{array}$ & $\begin{array}{c}\text { Fruit } \\
\text { weight } \\
\text { (g) }\end{array}$ & $\begin{array}{c}\text { No of } \\
\text { fruits } \\
\text { per } \\
\text { plant }\end{array}$ & $\begin{array}{c}\text { Fruit } \\
\text { yield } \\
\text { per } \\
\text { plant } \\
\text { (g) }\end{array}$ & $\begin{array}{l}\text { Fruit } \\
\text { yield per } \\
\text { hectare } \\
\text { (t) }\end{array}$ & $\begin{array}{c}\begin{array}{c}\text { No } \\
\text { of } \\
\text { seeds } \\
\text { per } \\
\text { fruit }\end{array} \\
\end{array}$ & $\begin{array}{c}\text { Seed } \\
\text { yield } \\
\text { per } \\
\text { plant } \\
\text { (g) }\end{array}$ & $\begin{array}{c}\text { Seed } \\
\text { yield } \\
\text { per } \\
\text { hectare } \\
(\mathbf{k g})\end{array}$ & $\begin{array}{c}\text { Harvest } \\
\text { Index } \\
(\%)\end{array}$ & $\begin{array}{c}\text { Ascorbic } \\
\text { acid } \\
\text { content } \\
\text { (mg/100 } \\
\text { g) }\end{array}$ \\
\hline$T_{1}$ & 5.08 & 2.19 & 4.91 & 23.70 & 116.64 & 4.32 & 22.73 & 4.78 & 177.25 & 39.76 & 95.13 \\
\hline $\mathbf{T}_{2}$ & 5.26 & 2.24 & 5.19 & 29.30 & 152.41 & 5.64 & 26.86 & 5.49 & 203.50 & 44.94 & 110.26 \\
\hline$T_{3}$ & 6.27 & 2.65 & 5.85 & 37.36 & 218.91 & 8.10 & 33.80 & 7.86 & 291.25 & 53.18 & 123.90 \\
\hline$T_{4}$ & 5.99 & 2.59 & 5.81 & 33.83 & 197.45 & 7.31 & 30.16 & 7.28 & 269.82 & 51.53 & 121.63 \\
\hline $\mathbf{T}_{5}$ & 5.03 & 2.10 & 4.87 & 27.23 & 132.12 & 4.89 & 24.83 & 4.96 & 183.80 & 42.54 & 89.56 \\
\hline$T_{6}$ & 5.93 & 2.48 & 5.78 & 31.66 & 182.44 & 6.75 & 28.86 & 6.54 & 242.54 & 47.81 & 129.83 \\
\hline $\mathbf{T}_{7}$ & 5.58 & 2.35 & 5.32 & 30.23 & 161.59 & 5.98 & 27.80 & 6.11 & 226.34 & 46.79 & 103.76 \\
\hline $\mathbf{T}_{8}$ & 5.79 & 2.44 & 5.61 & 41.06 & 231.01 & 8.55 & 31.96 & 8.27 & 306.39 & 55.26 & 115.06 \\
\hline $\operatorname{S.Em}( \pm)$ & 0.17 & 0.07 & 0.16 & 1.77 & 11.15 & 0.41 & 1.51 & 0.39 & 14.47 & 2.12 & 3.41 \\
\hline $\mathrm{CD}(0.05)$ & 0.52 & 0.22 & 0.49 & 5.39 & 33.84 & 1.25 & 4.58 & 1.18 & 43.91 & 6.43 & 10.35 \\
\hline
\end{tabular}

Table.3 Production economics of king chilli cultivation under different treatments

\begin{tabular}{|c|c|c|c|c|c|}
\hline Treatments & $\begin{array}{c}\text { Total cost } \\
\text { ( } \square / \mathbf{h a} \mathbf{)}\end{array}$ & $\begin{array}{c}\text { Yield } \\
\mathbf{( t / h a )}\end{array}$ & $\begin{array}{c}\text { Gross return } \\
\mathbf{(} \square / \mathbf{h a})\end{array}$ & $\begin{array}{c}\text { Net return } \\
\mathbf{(} \square / \mathbf{h a})\end{array}$ & B:C ratio \\
\hline $\mathbf{T}_{\mathbf{1}}$ & 286740 & 4.32 & 648000 & 361260 & 1.25 \\
\hline $\mathbf{T}_{\mathbf{2}}$ & 258740 & 5.64 & 846000 & 587260 & 2.26 \\
\hline $\mathbf{T}_{\mathbf{3}}$ & 307303 & 8.10 & 1215000 & 907697 & 2.95 \\
\hline $\mathbf{T}_{\mathbf{4}}$ & 297021 & 7.31 & 1096500 & 799479 & 2.69 \\
\hline $\mathbf{T}_{\mathbf{5}}$ & 283021 & 4.89 & 733500 & 450479 & 1.59 \\
\hline $\mathbf{T}_{\mathbf{6}}$ & 280030 & 6.75 & 1012500 & 732470 & 2.61 \\
\hline $\mathbf{T}_{\mathbf{7}}$ & 266031 & 5.98 & 897000 & 630969 & 2.37 \\
\hline $\mathbf{T}_{\mathbf{8}}$ & 242180 & 8.55 & 1282500 & 1040320 & 4.29 \\
\hline
\end{tabular}


The present investigation indicated that substitution of $100 \%$ RDN through vermicompost $\left(T_{3}\right)$ significantly influenced number of seeds per fruit (33.80), but remained at par with $\mathrm{T}_{4}(50 \% \mathrm{RDN}$ through $\mathrm{FYM}+50 \%$ RDN through vermicompost) and $\mathrm{T}_{8}(100 \% \mathrm{RDF})$. The increased seeds number under $T_{3}$ is presumably due to the presence of nutrients (both macro and micro) along with some amount of NPK in vermicompost. This result is in agreement with the findings of Sanjutha et al., (2008) who found highest number of seeds per fruit when organic fertilizers with high NPK content were applied. However, the highest seed yield per plant $(8.27 \mathrm{~g})$ and seed yield per hectare $(306.39 \mathrm{~kg} / \mathrm{ha})$ were recorded in plants supplied with $100 \%$ RDF $\left(\mathrm{T}_{8}\right)$, but remained at par with $\mathrm{T}_{3}(100 \%$ RDN through vermicompost) and $\mathrm{T}_{4}(50 \% \mathrm{RDN}$ through FYM $+50 \%$ RDN through vermicompost). The increase in seed yield under $T_{8}$ is possibly due to the equivalent reaction to increased number of fruits and fruit yield accomplished previously under this treatment.

The result obtained showed significant difference for harvest index between treatment combinations. However, 100 seed weight values had no notable variations. The significant harvest index (55.26\%) was obtained in plants supplied with $100 \%$ RDF $\left(\mathrm{T}_{8}\right)$, but remained at par with $\mathrm{T}_{3}(100 \% \mathrm{RDN}$ through vermicompost) and $\mathrm{T}_{4}(50 \% \mathrm{RDN}$ through FYM $+50 \%$ RDN through vermicompost). The increased harvest index of king chilli under $T_{8}$ is possibly due to increased fresh weight of plants and fruit yield at harvest.

\section{Quality parameter}

The findings of present experimentation indicated beneficial effect of different organic sources on quality of king chilli. Quality of king chilli is estimated generally in terms of vitamin $\mathrm{C}$ (ascorbic acid). As per the analysis, it was found that supplementation of 50\% RDN through FYM + 25\% RDN through vermicompost + Azospirillum $\left(\mathrm{T}_{6}\right)$ had significant influenced on ascorbic acid $(129.83 \mathrm{mg} / \mathrm{g})$ content followed by $\mathrm{T}_{3}(100 \%$ RDN through vermicompost) and $\mathrm{T}_{4}(50 \%$ RDN through FYM + 50\% RDN through vermicompost), all of them being at par. This findings has close conformity with Singh et al., (2014) who reported that vitamin $\mathrm{C}$ in chilli were recorded maximum with organics FYM (12.5 t/ha) + vermicompost (2.5 t/ha) + biofertilizer@ 2.5 kg/ha Azospirillum + PSB. The increased ascorbic acid content under $\mathrm{T}_{6}$ is possibly due to the integration effect of organic manures (FYM, vermicompost and biofertilizer) which must have boost the availability of soil nutrients for plant absorption. Consequently, specific enzymes must have activated for the ascorbate synthesis resulting in higher level of vitamin $\mathrm{C}$ content under $\mathrm{T}_{6}$. Hence, it is implicit that availability of specific soil nutrients play a crucial role in ascertaining this quality aspect of king chilli.

\section{Economics}

The technology acceptance by the farmers is dependent on the production economics of a crop. Among the various indicators of production economics, net profit and benefit cost ratio has a greater impact on the practical accessibility and acceptance of technology. Analysis of data, indicated beneficial effect of different organic sources of nitrogen on production economics of king chilli (Capsicum chinense Jacq.) The highest B:C ratio of 4.29 with a net profit ( $\square$ 1040320/ha) was exhibited by treatment application of $\mathrm{T}_{8}$ (100\% RDF) followed by $\mathrm{T}_{3}(100 \% \mathrm{RDN}$ through vermicompost) with a net profit ( $\square$ 907697/ha) and B:C ratio of 2.95. The reason of high profitability under $\mathrm{T}_{8}$ can be due to lower cost of inputs and higher yield. These 
results are also in line with those of Medhe et al., (2010) who reported that application of $100 \%$ NPK showed maximum benefit cost ratio of 4.68 .

From the present investigation, following conclusion may be drawn that application of $\mathrm{T}_{8}(100 \% \mathrm{RDF})$ resulted maximum growth, yield and net returns in king chilli. However, $\mathrm{T}_{8}$ remained statistically at par with $\mathrm{T}_{3}$ in certain growth, yield and quality parameters. The highest net return next to $\mathrm{T}_{8}$ was also recorded in $\mathrm{T}_{3}$. Thus, it could be inferred that among different organic sources of nitrogen, substitution of $100 \%$ RDN through vermicompost $\left(\mathrm{T}_{3}\right)$ showed promising results in the cultivation of king chilli under poly house condition. The present study clearly stated that vermicompost are effective alternatives as a source of nutrients and have a potential to improve the plant growth, fruit yield and quality aspect of king chilli and thus avoid use of harmful chemical fertilizers.

\section{References}

Abu-Zahra, T.R. (2012). Vegetative, flowering and yield of sweet pepper as influenced by agricultural practices. Middle East Journal of Scientific Research, 11(9): 1220-1225.

Adhikari, P., Khanal, A. and Subedi, R. (2016). Effect of different sources of organic manure on growth and yield of sweet pepper. Advances in Plants and Agriculture Research, 5(3).

Alex, A.R. and Eliakira, K. (2014). Effect of NPK and Minjingu mazao fertilizers on the performance of sweet pepper in Morogoro, Tanzania. Direct Research Journal of Agriculture and Food Science, 2(11): 179-183.

Baloch, Q.B., Chachar, Q.I. and Tareen, M.N. (2008). Effect of foliar application of macro and micro nutrients on production of green chilies (Capsicum annuum L.).
Journal of Agricultural Technology, 4(2): 177-184.

Bilal, H., Aman, F., Ullah, I., Awan, A.A., Ullah, S., Khan, S., Aamir, M., Khan, M.A. and Rome, B. (2019). Response of chilli varieties to various sources of organic fertilizers. Journal of Agricultural and Biological Science, 13(12): 15-24.

Bora, G. (2000). Evaluation of different types of Bhut Jolokia for pungency and colour. M.Sc. (Agri) Thesis, Assam Agricultural University, Jorhat, Assam.

Bosland, P.W. and Baral, J.B. (2007). 'Bhut Jolokia': The world's hottest known chile pepper is a putative naturally occurring interspecific hybrid. HortScience, 42(2): 222-224.

Chassy, A.W., Bui, L., Renaud, E.N., Van Horn, M. and Mitchell, A.E. (2006). Three year comparison of the content of antioxidant microconstituents and several quality characteristics in organic and conventionally managed tomatoes and bell peppers. Journal of Agricultural and Food Chemistry, 54: 8244-8252.

Hussein Hussein Alhrout (2017). Response of growth and yield components of sweet pepper to two different kinds of fertilizers under green house conditions in Jordan. Journal of Agricultural Science, 9(10): 265-272.

Khandaker, M.M., Rohani, F., Dalorima, T. and Nashriyah M. (2017). Effects of Different Organic Fertilizers on Growth, Yield and Quality of Capsicum annuum L. Var. Kulai (Red Chilli) Biosciences Biotechnology Research Asia, 14(1): 185192.

Khutate, N.G., Mendhe, S.N., Dongarkar, K.P., Gudadhe, N.N. and Gavande, V.H. (2005). Effect of nutrient management treatments on growth and yield of soybean. Journal of Soils and Crops, 15(2): 411-414.

Medhe, N.K., Gawade, B.V., Randive, S.N. 
and Temkar, B.G. (2010). Effect of integrated nitrogen management on yield and economics of green chilli (Capsicum annuum L.) production. Green Farming, 1(3): 260-262.

Meitei, W.I., Singh, N.G. and Devi, H.J. (2005). Estimation of leaf area of perennial pungent chillies. Horticulture Journal, 18(1): 51-55.

Olson, R.A., Army, J.J., Hanway, J.J. and Kilmer, U.J. (1971). Premature fruit drop of hot pepper (Capsicum frutescens). The Legion of Agriculture Research Bulletin, 2: 86.

Omogoye, A.M. (2015). Efficacy of NPK and cow dung combinations on performance of chili pepper (Capiscum annuum L.) and their influence on soil properties. Journal of Agriculture and Veterinary Science, 8(7): 31-35.

Pavan, A.S. (2013). Developing organic manurial practices for dry chili (Capsicum annuum L.) production in southern transition zone of Karnataka, Doctoral dissertation, University of Agricultural Sciences, Bengaluru.

Rangana, S. (1977). Manual of Analysis for Fruit and Vegetable Products. Tata Mc Graw Hill Publishing Co. Ltd., New Delhi.

Revanappa, Nalawadi, U.G. and Madalageri, M.B. (1997). Influence of nitrogen on fruit parameters and yield parameters in green chilli genotypes. Karnataka Journal of Agriculture Sciences, 10: 1060-1064.

Sanjutha, S., Subramanian, C., Rani, I., and Maheswari, J. (2008). Integrated Nutrient
Management in Andrographis paniculata. Research Journal of Agriculture and Biological Sciences, 4(2): 141-145.

Riahi, A., Hdider, C., Sanaa, M., Tarchoun, N., Kheder, M.B. and Guezal, I. (2009). Effect of conventional and organic productions systems on the yield and quality of field tomato cultivars grown in Tunisia. Journal of the Science of Food and Agriculture, 89: 2275-2282.

Singh, C.K., John, S.A. and Jaiswal, D. (2014): Effect of organics on growth, yield and biochemical parameters of chilli (Capsicum annuum L.). IOSR Journal of Agriculture and Veterinary Science, 7(7): 27-32.

Singh, S.K., Kumar, S., Yadav, Y.C. and Kumar, A. (2012). Effect of NPK levels on growth yield and quality of Okra cv. Arka Anamika. HortFlora Research Spectrum, 1(2): 190-192.

Sivakumar, J., Muralidhar, A.P. and Kumargouda, V. (1999). Fertilizer and irrigation use efficiency as influenced by furrow and ferti-drip irrigation in capsicum-maize sunflower cropping sequence. Proceedings of National Seminar on problems and prosects of micro irrigation. A Critical Appraisal Nov. 19-29, Bangalore pp. 74-78.

Yadav, H. and Vijayakumari, B. (2003). Influence of vermi compost with organic and inorganic manures on biometric and yield parameters of chilli (Capsicum annuum L.). Crop Research, 25(2): 236243.

\section{How to cite this article:}

Humtu Rangai, A. K. Bijaya Devi, K. James Singh and Jekendra Singh, S. 2020. Effect of Organic Sources of Nitrogen on Growth, Yield and Quality of King Chilli (Capsicum chinense Jacq.) under Poly House Condition. Int.J.Curr.Microbiol.App.Sci. 9(11): 3171-3180. doi: https://doi.org/10.20546/ijcmas.2020.911.382 